\title{
Promising Chickpea based Cropping Systems for Vertisols of Andhra Pradesh
}

\author{
K. Prabhakar, V. Sumathi, T. Giridhar Krishna, P. Sudhakar, S. Jaffar Basha
}

10.18805/IJARe.A-5898

\begin{abstract}
Background: The promising cropping system over the years in vertisols of Andhra Pradesh is fallow- chickpea and the yields and profits were declining gradually. Farmers were switched over to double cropping system with kharif cereals before chickpea cultivation. Most of the farmers burnt the preceding crop residues which lead to harmful effects on soil flora and air pollution. Preceding crop residues incorporation will improve the soil moisture content, soil carbon content and stabilize the yields of chickpea and system productivity. The present study was conducted to study the impact of crop residues on system productivity and to find suitable cropping system.

Methods: Field experiments were conducted during Kharif and rabi seasons of 2018-19 and 2019-20 with split- split plot design and replicated thrice.

Result: Foxtail millet-chickpea cropping system recorded higher chickpea equivalent yields, during both years of investigation followed by greengram-chickpea cropping system. Greengram-chickpea cropping system recorded high production use efficiency (48 and 69 $\mathrm{kg} \mathrm{ha}^{-1}$ in 2018-19 and 2019-20 respectively) followed by foxtail millet-chickpea (43 and $61 \mathrm{~kg} \mathrm{ha}^{-1}$ in 2018-19 and 2019-20 respectively). By the end of the year of experimentation, greengram-chickpea cropping system showed higher values of SYI, due to higher organic carbon and added biological nitrogen than foxtail millet-chickpea cropping system.
\end{abstract}

Key words: Chickpea equivalent yields, Cropping system, LUE, PE, SYI.

\section{INTRODUCTION}

Now in India farmers concentrate mainly on monocropping system which is subjected to high degree of income and can decrease system productivity, reduction in profitability and declining in soil health. Continuous use of chemical fertilizers in intensive cropping system leads to imbalance of nutrients in soil, which has adverse effect on soil health and also on crop yields (Hashim et al. 2015). Inclusion of legumes and cereals in cropping system have advantage beyond $\mathrm{N}$ addition, recycling from soil layers, minimizing soil compaction, protecting soil from erosion, increasing soil organic matter through root biomass and leaf fall and minimizing the harmful allopathic effects (Jain et al. 2015).

In vertisols of scarce rainfall zone of Andhra Pradesh with unimodel distribution of rainfall mainly during kharif season, chickpea is grown as a rabi crop based on residual soil moisture. The promising cropping system over the years in this area is fallow- chickpea or cereal-chickpea, particularly with maize/foxtail millet-chickpea cropping system. From point of view of biological value and protein efficiency, pulse-chickpea cropping system provides better nutritional standards, sustain yields and soil fertility

The chickpea area in Andhra Pradesh under double cropping system is increasing recently due to higher yields and profits within short crop growing period by exploiting residual moisture. Since very little scope exists for horizontal growth the alternative seems by achieving vertical growth through increasing its productivity level. Under double cropping system, preceiding crop residues can incorporate to sustain the soil moisture which is the key factor to improve
Department of Agronomy, Regional Agricultural Research Station, Acharya N.G. Ranga Agricultural University, Nandyal-518 502, Andhra Pradesh, India.

Corresponding Author: K. Prabhakar, Department of Agronomy, Regional Agricultural Research Station, Acharya N.G. Ranga Agricultural University, Nandyal-518 502, Andhra Pradesh, India. Email: kprabhakar7714@gmail.com

How to cite this article: Prabhakar, K., Sumathi, V., Giridhar Krishna, T., Sudhakar, P. and Jaffar Basha, S. (2022). Promising Chickpea based Cropping Systems for Vertisols of Andhra Pradesh. Indian Journal of Agricultural Research. DOI: 10.18805/IJARe.A-5898.

Submitted: 23-08-2021 Accepted: 04-12-2021 Online: 28-02-2022

soil moisture content and organic carbon content of the soil as chickpea is mostly grown in residual moisture condition which decides the yields and returns.

\section{MATERIALS AND METHODS}

Field experiments were carried out for two consecutive kharif and rabi seasons for the year 2018-19 and 2019-20 at R.A.R.S. Farm, Nandyal, Andhra Pradesh. The treatments comprised of three crop residue incorporations viz., foxtail millet, $\left(C_{1}\right)$ greengram $\left(C_{2}\right)$ and fallow $\left(C_{3}\right)$ as main plot treatments and four times of sowing viz. October $2^{\text {nd }} F N\left(D_{1}\right)$, November $1^{\text {st }} \mathrm{FN}\left(\mathrm{D}_{2}\right)$, November $2^{\text {nd }} \mathrm{FN}\left(\mathrm{D}_{3}\right)$ and December $1^{\text {st }} \mathrm{FN}\left(\mathrm{D}_{4}\right)$ as sub plot treatments and three irrigation schedules as sub- sub plots with irrigation at pre-flowering stage $\left(I_{1}\right)$, irrigation at pod development stage $\left(I_{2}\right)$ and irrigation at pre-flowering and pod development stage $\left(\mathrm{I}_{3}\right)$ 
Promising Chickpea Based Cropping Systems for Vertisols of Andhra Pradesh

During kharif season, foxtail millet and greengram crops were raised as bulk crops in respective main plots and crop residues were incorporated after harvest of economic parts viz., panicles of foxtail millet and pods of greengram. Experimental design was split-split plot, with three replications.

The site was situated at an altitude of $216 \mathrm{~m}$ above mean sea level at $15^{\circ} 29^{\prime} 19^{\prime \prime} \mathrm{N}$ latitude and $78^{\circ} 29^{\prime} 11^{\prime \prime} \mathrm{E}$ longitude, mostly under rainfed conditions, categorized in the scarce rainfall agro-climatic zone of Andhra Pradesh. The meteorological data of maximum and minimum temperature, rainfall, number of rainy days, morning and evening relative humidity and wind speed were recorded from meteorological observatory, Regional Agricultural Research Station, Nandyal near the experimental site, during the period of crop growth. Soil of the site was medium in fertility and slightly saline in reaction having $\mathrm{pH} 8.42$, electrical conductivity $0.24 \mathrm{dSm}^{-1}$, organic carbon $0.32 \%$ with available nitrogen, phosphorus and potassium 143, 53 and $451 \mathrm{~kg} / \mathrm{ha}$, respectively. Sowing of seeds was done in rows, $30 \mathrm{~cm}$ apart with $10 \mathrm{~cm}$ between plants. An amount of $20 \mathrm{~kg}$ nitrogen and $50 \mathrm{~kg} \mathrm{P}_{2} \mathrm{O}_{5}$ per hectare was applied through urea and SSP as basal. Sowing was done in four intervals as $D_{1}$ on October $2^{\text {nd }}$ fortnight, $D_{2}$ on November $1^{\text {st }}$ fortnight, $D_{3}$ on November $2^{\text {nd }}$ fortnight, $D_{4}$ on December $1^{\text {st }}$ fortnight, in respective treatment plots. Healthy and matured seeds of desi chickpea variety NBeG-3 having high germination percentage were used for sowing. Seed rate @ 50 kg ha-1 was adopted and sown in the open furrows made with the help of hand hoe. The seeds were dropped to a depth of 5 $\mathrm{cm}$ and covered thoroughly. System productivity indicators, land use efficiency, production efficiency, sustainable yield index equivalent yields and economics were calculated based on standard formulas:

\section{Land use efficiency}

Land use efficiency of cropping system was calculated by using the following formula and expressed in percentage.

Land use efficiency $(\%)=$

$$
\frac{\text { Duration of crops in a year }}{365} \times 100
$$

\section{Production efficiency}

Production efficiency of cropping system was calculated by using the following formula and expressed in $\mathrm{kg} \mathrm{ha}^{-1}$ day $^{-1}$ ) based on chickpea equivalence yields.

Production efficiency $\left(\mathrm{kg} \mathrm{ha}^{-1}\right.$ day $\left.^{-1}\right)=$

Total production of a system

Total duration of the cropping system

\section{Sustainable yield index}

The sustainable yield index for foxtail millet / greengram chickpea cropping system was worked out by the formula given by Tomar and Tiwari (1990) based on chickpea equivalence yields.
$Y I=$

Mean chickpea equivalence yields of cropping system -

Standard daviation of chickpea equivalence yields

Maximum chickpea equivalence yields of cropping system

\section{Equivalent yields and economics}

The seed yield of the kharif crops was converted in to chickpea equivalents on the basis of price of seed of kharif crops involved in the cropping system.

The total cost of cultivation of double cropping system $\left(\mathrm{ha}^{-1}\right)$ was calculated for each treatment on the basis of input cost of both the seasons. Gross returns $\left(\mathrm{ha}^{-1}\right)$ was computed by considering the prevailing market price of the outputs. Net return $\left(\mathrm{ha}^{-1}\right)$ were arrived by deducting the cost of cultivation from gross returns of corresponding cropping system. Cost benefit ratio was worked out for each system.

\section{RESULTS AND DISCUSSION}

\section{Cropping system equivalent yields and economics}

System productivity was estimated by converting foxtail millet and green gram yields into to chickpea equivalent yields and presented in Table 1 and outline indicates that foxtail millet - chickpea cropping system recorded higher chickpea equivalent yields, during both years of investigation followed by greengram - chickpea cropping system. Fallow - chickpea cropping system recorded lower values of chickpea equivalent yields in both years of study.

Cropping system cost of cultivation, gross and net returns and benefit cost ratio was calculated for all treatments for both years of study and presented in Fig. 1 and 2). Gross and net returns were highest with foxtail milletchickpea cropping system followed by greengram - chickpea cropping system. Minimum returns were obtained when fallow-chickpea system adopted.

Under rainfed condition cultivation of foxtail millet / greengram in kharif season and incorporation of their residues before chickpea sowing effect on productivity and profitability of cropping system instead of fallow chickpea in vertisols. The same line of results was reported by Amgain et al. (2013).

\section{Land use efficiency (LUE) (\%)}

Land use efficiency (\%) of different chickpea based cropping systems under study was calculated and mean values were shown in Table 2. The data indicated that both foxtail millet -chickpea and greengram-chickpea cropping system increased the LUE by $20-25$ per cent over fallow- chickpea cropping system in all four times of sowing. Hence, under rainfed vertisols foxtail millet-chickpea (46\%) and greengram -chickpea (45.5\%) was found suitable cropping system with high land use efficiency. similar line of results were reported by Dudhra et al. (2002).

\section{Production efficiency}

Production efficiency of three chickpea based cropping systems under different time of sowing were worked out and 
presented in Table 1. The data indicated that greengram chickpea cropping system recorded high production use efficiency (48 and $69 \mathrm{~kg} \mathrm{ha}^{-1}$ in 2018-19 and 2019-20 respectively) followed by foxtail millet-chickpea (43 and 61 $\mathrm{kg} \mathrm{ha}^{-1}$ in 2018-19 and 2019-20 respectively) cropping system during both years of study. Fallow-chickpea cropping system recorded lower values in all four rabi chickpea sowing time.

These results indicated that greengram - chickpea and foxtail millet - chickpea were more productive systems under double cropping systems in vertisols of Andhra Pradesh. Pacharne et al. (2018) also reported that groundnut- onion cropping system recorded significantly maximum total productivity, production use efficiency, economic efficiency and maximum monetary returns when compared with groundnut- wheat/ groundnut- chickpea cropping system.

\section{Sustainable yield index}

The sustainable yield index values calculated for different treatments of foxtail millet / greengram-chickpea cropping system clearly showed the yield sustainability with crop residue incorporations and time of sowing of chickpea crop (Table 1).

The sustainable yield index values were higher during second year of study due to adequate rains, which helped in better decomposition of incorporated residues. By the end

Table 1: Chickpea equivalent yield of foxtail millet/greengram - chickpea double cropping system.

\begin{tabular}{|c|c|c|c|c|c|c|c|c|}
\hline \multirow{2}{*}{ Treatments } & \multicolumn{4}{|c|}{ 2018-19 } & \multicolumn{4}{|c|}{$2019-20$} \\
\hline & Foxtail millet & Greengram & Chickpea & ${ }^{*} \mathrm{CEY}$ & Foxtail millet & Greengram & Chickpea & ${ }^{*} \mathrm{CEY}$ \\
\hline$C_{1} D_{1} I_{1}$ & 1798 & - & 992 & 1639 & 1871 & - & 1576 & 2926 \\
\hline$C_{1} D_{1} I_{2}$ & 1789 & - & 1076 & 1720 & 1859 & - & 1738 & 2908 \\
\hline$C_{1} D_{1} I_{3}$ & 1795 & - & 1461 & 2107 & 1872 & - & 2170 & 2928 \\
\hline $\mathrm{C}_{1} \mathrm{D}_{2} \mathrm{I}_{1}$ & 1792 & - & 1128 & 1773 & 1855 & - & 1942 & 2955 \\
\hline $\mathrm{C}_{1} \mathrm{D}_{2} \mathrm{I}_{2}$ & 1785 & - & 1321 & 1964 & 1870 & - & 2138 & 2922 \\
\hline $\mathrm{C}_{1} \mathrm{D}_{2} \mathrm{I}_{3}$ & 1789 & - & 1951 & 2595 & 1866 & - & 2514 & 2956 \\
\hline $\mathrm{C}_{1} \mathrm{D}_{3} \mathrm{I}_{1}$ & 1779 & - & 914 & 1554 & 1889 & - & 1681 & 2901 \\
\hline $\mathrm{C}_{1} \mathrm{D}_{3} \mathrm{I}_{2}$ & 1791 & - & 1192 & 1837 & 1868 & - & 1838 & 2925 \\
\hline $\mathrm{C}_{1} \mathrm{D}_{3} \mathrm{I}_{3}$ & 1788 & - & 1797 & 2441 & 1890 & - & 2163 & 2919 \\
\hline$C_{1} D_{4} I_{1}$ & 1779 & - & 656 & 1296 & 1879 & - & 1115 & 2939 \\
\hline$C_{1} D_{4} I_{2}$ & 1789 & - & 870 & 1514 & 1855 & - & 1504 & 2901 \\
\hline$C_{1} D_{4} I_{3}$ & 1787 & - & 1391 & 2034 & 1874 & - & 2020 & 2931 \\
\hline $\mathrm{C}_{2} \mathrm{D}_{1} \mathrm{I}_{1}$ & - & 534 & 836 & 1498 & - & 783 & 1602 & 2847 \\
\hline $\mathrm{C}_{2} \mathrm{D}_{1} \mathrm{I}_{2}$ & - & 539 & 960 & 1628 & - & 785 & 1814 & 3062 \\
\hline $\mathrm{C}_{2} \mathrm{D}_{1} \mathrm{I}_{3}$ & - & 536 & 1547 & 2212 & - & 791 & 2081 & 3338 \\
\hline $\mathrm{C}_{2} \mathrm{D}_{2} \mathrm{I}_{1}$ & - & 549 & 987 & 1668 & - & 783 & 1960 & 3205 \\
\hline $\mathrm{C}_{2} \mathrm{D}_{2} \mathrm{I}_{2}$ & - & 537 & 1126 & 1792 & - & 790 & 1951 & 3207 \\
\hline $\mathrm{C}_{2} \mathrm{D}_{2} \mathrm{I}_{3}$ & - & 539 & 1798 & 2466 & - & 778 & 2374 & 3611 \\
\hline $\mathrm{C}_{2} \mathrm{D}_{3} \mathrm{I}_{1}$ & - & 542 & 944 & 1616 & - & 785 & 1722 & 2970 \\
\hline $\mathrm{C}_{2} \mathrm{D}_{3} \mathrm{I}_{2}$ & - & 536 & 1037 & 1702 & - & 793 & 2007 & 3268 \\
\hline $\mathrm{C}_{2} \mathrm{D}_{3} \mathrm{I}_{3}$ & - & 541 & 1643 & 2314 & - & 779 & 2098 & 3336 \\
\hline $\mathrm{C}_{2} \mathrm{D}_{4} \mathrm{I}_{1}$ & - & 540 & 614 & 1284 & - & 792 & 1043 & 2302 \\
\hline $\mathrm{C}_{2} \mathrm{D}_{4} \mathrm{I}_{2}$ & - & 538 & 744 & 1411 & - & 776 & 1404 & 2638 \\
\hline $\mathrm{C}_{2} \mathrm{D}_{4} \mathrm{I}_{3}$ & - & 546 & 1461 & 2138 & - & 779 & 1882 & 3120 \\
\hline $\mathrm{C}_{3} \mathrm{D}_{1} \mathrm{I}_{1}$ & - & - & 541 & 541 & - & - & 1162 & 1162 \\
\hline $\mathrm{C}_{3} \mathrm{D}_{1} \mathrm{I}_{2}$ & - & - & 628 & 628 & - & - & 1437 & 1437 \\
\hline $\mathrm{C}_{3} \mathrm{D}_{1} \mathrm{I}_{3}$ & - & - & 1357 & 1357 & - & - & 1723 & 1723 \\
\hline $\mathrm{C}_{3} \mathrm{D}_{2} \mathrm{I}_{1}$ & - & - & 792 & 792 & - & - & 1384 & 1384 \\
\hline $\mathrm{C}_{3} \mathrm{D}_{2} \mathrm{I}_{2}$ & - & - & 1035 & 1035 & - & - & 1365 & 1365 \\
\hline $\mathrm{C}_{3} \mathrm{D}_{2} \mathrm{I}_{3}$ & - & - & 1583 & 1583 & - & - & 1985 & 1985 \\
\hline $\mathrm{C}_{3} \mathrm{D}_{3} \mathrm{I}_{1}$ & - & - & 680 & 680 & - & - & 1196 & 1196 \\
\hline $\mathrm{C}_{3} \mathrm{D}_{3} \mathrm{I}_{2}$ & - & - & 934 & 934 & - & - & 1234 & 1234 \\
\hline $\mathrm{C}_{3} \mathrm{D}_{3} \mathrm{I}_{3}$ & - & - & 1475 & 1475 & - & - & 1990 & 1990 \\
\hline $\mathrm{C}_{3} \mathrm{D}_{4} \mathrm{I}_{1}$ & - & - & 566 & 566 & - & - & 953 & 953 \\
\hline $\mathrm{C}_{3} \mathrm{D}_{4} \mathrm{I}_{2}$ & - & - & 889 & 889 & - & - & 1166 & 1166 \\
\hline $\mathrm{C}_{3} \mathrm{D}_{4} \mathrm{I}_{3}$ & - & - & 1224 & 1224 & - & - & 1770 & 1770 \\
\hline
\end{tabular}

${ }^{*} \mathrm{CEY}$ : Chickpea equivalent yield. 
of the year of experimentation, greengram-chickpea cropping system showed higher values of SYI, due to higher organic carbon and added biological nitrogen. The lower SYI values were with fallow-chickpea cropping system, due to single season yields.

\section{Soil carbon sequestration}

Data on soil carbon content at different crop growth stages were calculated and shown in Table 3. After crop residue incorporation, when the sowing of rabi chickpea delayed from October to December, the soil organic carbon pool increased, however, the chickpea seed yield was not proportional to soil organic pool due to crop weather relations.

The soil organic content during the crop period of chickpea indicated that crop residues incorporation treatments significantly influenced the soil carbon sequestration only during rabi 2019-20, but not by time of sowing and irrigation treatments. Maximum soil carbon

Table 2: Land use efficiency (LUE), production efficiency (PE) and sustainable yield index (SYI) of different chickpea based cropping systems under different times of sowing.

\begin{tabular}{|c|c|c|c|c|c|c|}
\hline \multirow{2}{*}{ Treatments } & \multicolumn{2}{|c|}{ LUE (\%) } & \multicolumn{2}{|c|}{$P E\left(\mathrm{~kg} \mathrm{ha}^{-1}\right.$ day $\left.^{-1}\right)$} & \multicolumn{2}{|r|}{ SYI } \\
\hline & Rabi, 2018 & Rabi, 2019 & Rabi, 2018 & Rabi, 2019 & Rabi, 2018 & Rabi, 2019 \\
\hline \multicolumn{7}{|l|}{ Foxtail millet-chickpea cropping system } \\
\hline FM- chickpea October $2^{\text {nd }} F N$ sowing & 48 & 47 & 40 & 57 & 0.49 & 0.58 \\
\hline FM- chickpea November $1^{\text {st }} F N$ sowing & 46 & 47 & 47 & 67 & 0.60 & 0.60 \\
\hline FM- chickpea November 2nd FN sowing & 47 & 47 & 44 & 61 & 0.53 & 0.59 \\
\hline FM- chickpea December $1^{\text {st }} \mathrm{FN}$ sowing & 45 & 45 & 40 & 58 & 0.41 & 0.58 \\
\hline Mean & 46 & 46 & 43 & 61 & 0.51 & 0.59 \\
\hline \multicolumn{7}{|l|}{ Greengram-chickpea cropping system } \\
\hline GG- chickpea October $2^{\text {nd }} F N$ sowing & 47 & 46 & 47 & 63 & 0.47 & 0.63 \\
\hline GG- chickpea November $1^{\text {st }} \mathrm{FN}$ sowing & 45 & 46 & 52 & 75 & 0.55 & 0.71 \\
\hline GG- chickpea November $2^{\text {nd }} \mathrm{FN}$ sowing & 45 & 46 & 50 & 73 & 0.51 & 0.66 \\
\hline GG- chickpea December $1^{\text {st }} F N$ sowing & 44 & 44 & 44 & 67 & 0.48 & 0.52 \\
\hline Mean & 45 & 46 & 48 & 69 & 0.50 & 0.63 \\
\hline \multicolumn{7}{|l|}{ Fallow-chickpea cropping system } \\
\hline Fallow- chickpea October $2^{\text {nd }} F N$ sowing & 29 & 28 & 15 & 26 & 0.12 & 0.18 \\
\hline Fallow- chickpea November $1^{\text {st }} \mathrm{FN}$ sowing & 27 & 28 & 21 & 30 & 0.22 & 0.22 \\
\hline Fallow- chickpea November $2^{\text {nd }} \mathrm{FN}$ sowing & 27 & 28 & 19 & 27 & 0.18 & 0.18 \\
\hline Fallow- chickpea December $1^{\text {st }} \mathrm{FN}$ sowing & 25 & 25 & 18 & 25 & 0.18 & 0.14 \\
\hline Mean & 27 & 27 & 18 & 27 & 0.18 & 0.18 \\
\hline
\end{tabular}

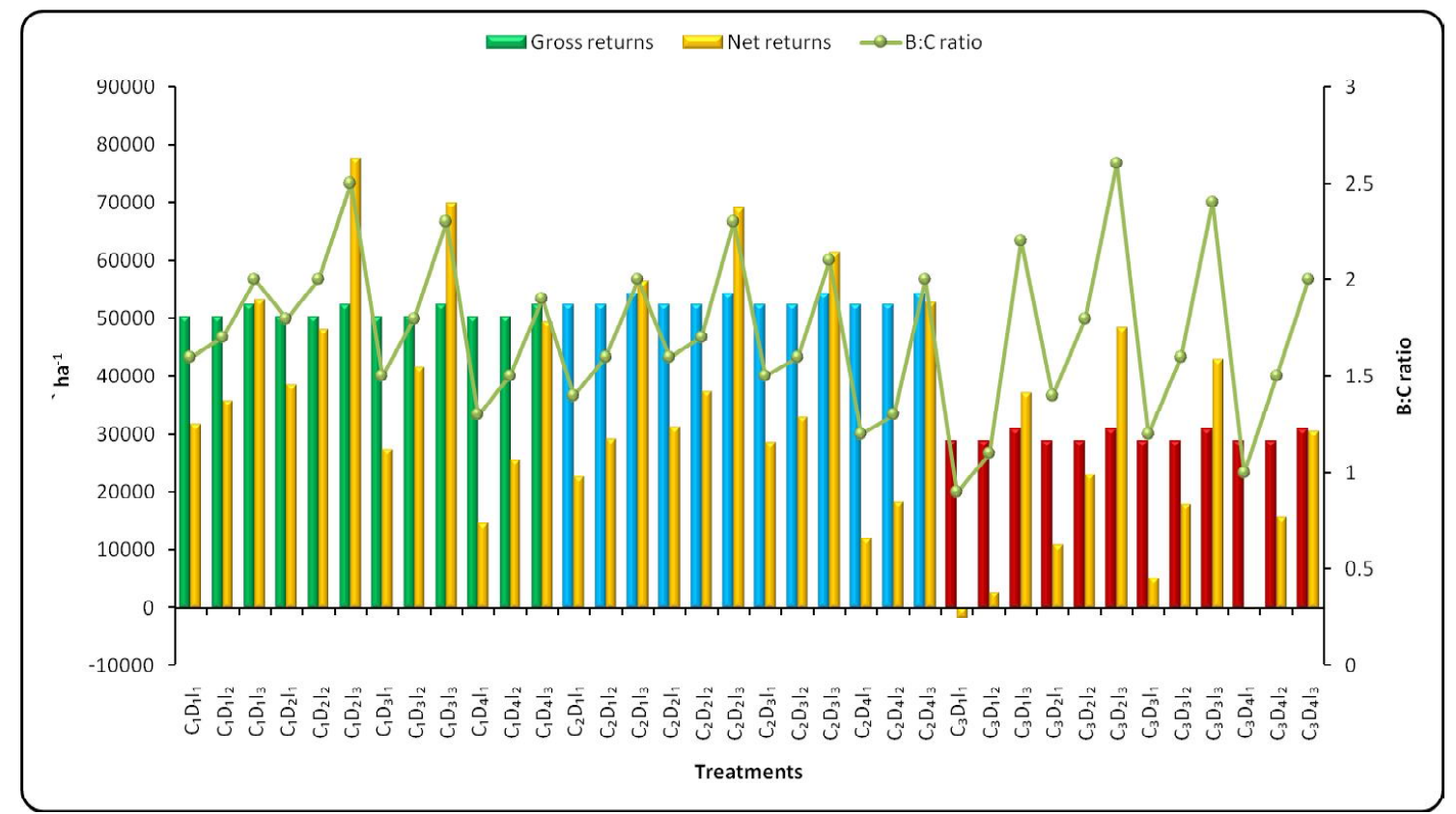

Fig 1: Economics of chickpea based cropping systems 2018-19. 


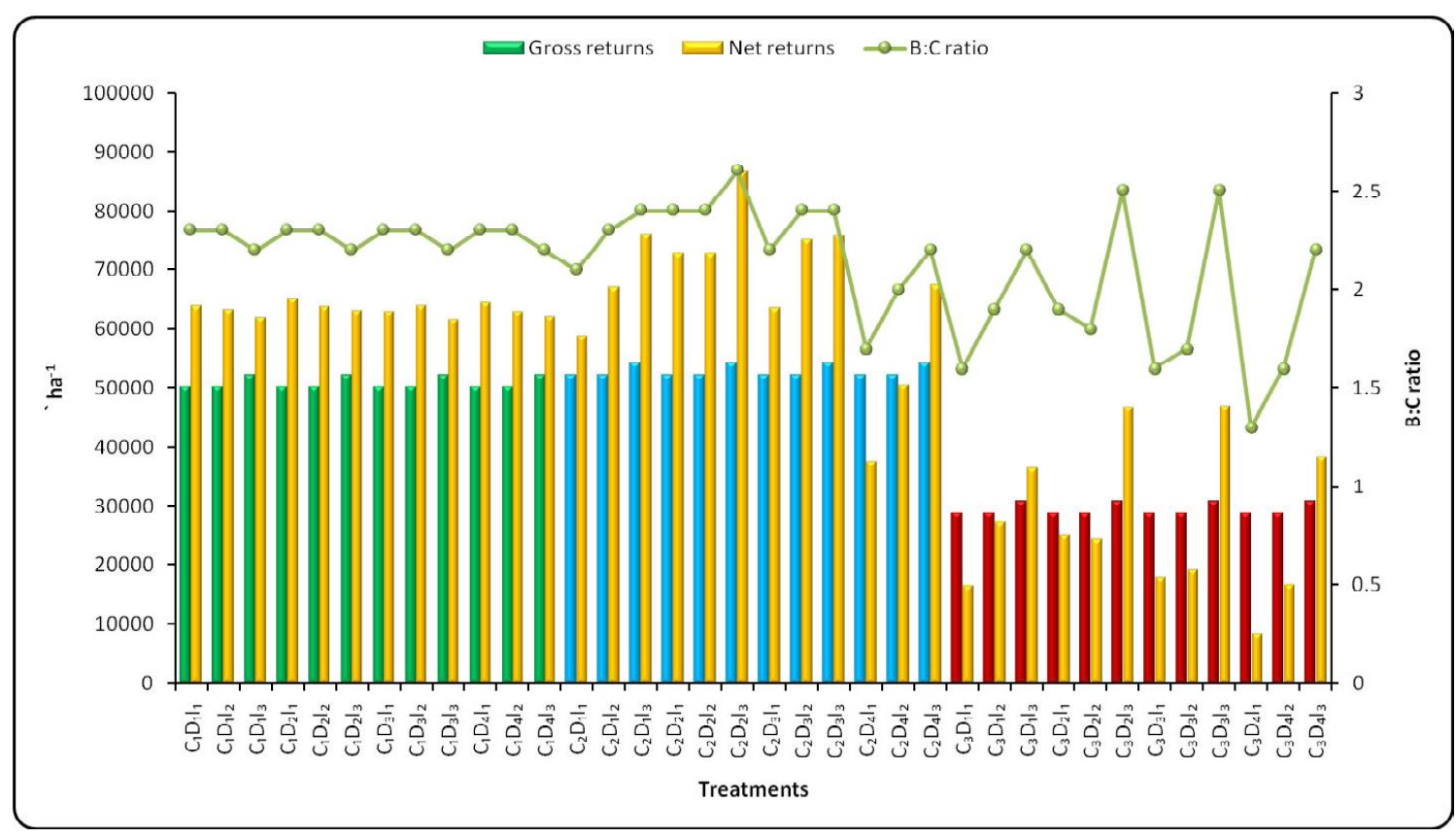

Fig 2: Economics of chickpea based cropping systems 2019-20.

Table 3: Soil carbon sequestration ( $\left.\mathrm{t} \mathrm{ha}^{-1}\right)$ in chickpea field as influenced by crop residue incorporation, time of sowing and irrigation.

\begin{tabular}{|c|c|c|c|c|c|c|}
\hline \multirow{2}{*}{ Treatments } & \multicolumn{2}{|c|}{30 DAS } & \multicolumn{2}{|c|}{60 DAS } & \multicolumn{2}{|c|}{ At harvest } \\
\hline & Rabi, 2018 & Rabi, 2019 & Rabi, 2018 & Rabi, 2019 & Rabi, 2018 & Rabi, 2019 \\
\hline \multicolumn{7}{|l|}{ Crop residue incorporation } \\
\hline $\mathrm{C}_{1}:$ Foxtail millet & 6.16 & 6.37 & 6.37 & 7.12 & 6.37 & 9.93 \\
\hline $\mathrm{C}_{2}:$ Greengram & 5.81 & 6.18 & 6.18 & 6.93 & 6.36 & 9.18 \\
\hline $\mathrm{C}_{3}:$ Fallow & 6.18 & 6.06 & 6.15 & 5.62 & 6.18 & 6.18 \\
\hline $\mathrm{SEm} \pm$ & 0.263 & 0.319 & 0.353 & 0.223 & 0.278 & 0.292 \\
\hline$C D(P=0.05)$ & NS & NS & NS & 0.64 & NS & 0.87 \\
\hline \multicolumn{7}{|l|}{ Time of sowing } \\
\hline $\mathrm{D}_{1}:$ October $2^{\text {nd }} \mathrm{FN}$ & 6.18 & 6.37 & 6.18 & 6.75 & 5.81 & 6.93 \\
\hline $\mathrm{D}_{2}:$ November $1^{\text {st }} \mathrm{FN}$ & 6.06 & 6.18 & 6.75 & 6.93 & 7.12 & 8.25 \\
\hline $\mathrm{D}_{3}:$ November $2^{\text {nd }} \mathrm{FN}$ & 6.18 & 6.56 & 6.37 & 6.75 & 6.56 & 7.31 \\
\hline $\mathrm{D}_{4}:$ December $1^{\text {st }} \mathrm{FN}$ & 5.81 & 5.81 & 6.01 & 6.73 & 6.05 & 6.93 \\
\hline SEm \pm & 0.153 & 0.209 & 0.271 & 0.179 & 0.187 & 0.198 \\
\hline$C D(P=0.05)$ & NS & NS & NS & NS & NS & NS \\
\hline \multicolumn{7}{|l|}{ Time of Irrigation } \\
\hline $\mathrm{I}_{1}:$ Irrigation at pre-flowering stage & 6.56 & 6.75 & 6.75 & 6.93 & 6.93 & 7.31 \\
\hline $\mathrm{I}_{2}:$ Irrigation at pod development stage & 6.00 & 6.37 & 6.18 & 6.56 & 6.37 & 6.93 \\
\hline $\mathrm{I}_{3}$ : Irrigation at pre-flowering and poddevelopment stage & 6.93 & 6.75 & 6.75 & 6.56 & 6.18 & 7.68 \\
\hline $\mathrm{SEm} \pm$ & 0.075 & 0.093 & 0.085 & 0.092 & 0.102 & 0.082 \\
\hline$C D(P=0.05)$ & NS & NS & NS & NS & NS & NS \\
\hline \multicolumn{7}{|l|}{ Interaction } \\
\hline \multicolumn{7}{|l|}{$C \times D$} \\
\hline $\mathrm{SEm} \pm$ & 0.272 & 0.325 & 0.177 & 0.823 & 0.723 & 0.257 \\
\hline$C D(P=0.05)$ & NS & NS & NS & NS & NS & NS \\
\hline \multicolumn{7}{|l|}{$C \times I$} \\
\hline $\mathrm{SEm} \pm$ & 0.305 & 0.256 & 0.211 & 0.429 & 0.362 & 0.606 \\
\hline$C D(P=0.05)$ & NS & NS & NS & NS & NS & NS \\
\hline \multicolumn{7}{|l|}{$D \times I$} \\
\hline SEm \pm & 0.421 & 0.309 & 0.615 & 0.633 & 0.301 & 0.326 \\
\hline$C D(P=0.05)$ & NS & NS & NS & NS & NS & NS \\
\hline \multicolumn{7}{|l|}{$C \times D \times I$} \\
\hline SEm \pm & 0.386 & 0.492 & 0.312 & 0.531 & 0.621 & 0.415 \\
\hline$C D(P=0.05)$ & NS & NS & NS & NS & NS & NS \\
\hline
\end{tabular}


content was recorded with foxtail millet crop residue incorporation $7.19\left(\mathrm{t} \mathrm{ha}^{-1}\right)$ and $9.93 \mathrm{t} \mathrm{ha}^{-1}$ at $60 \mathrm{DAS}$ and at harvest stages, respectively and on par with greengram crop residue incorporation values of $6.93 \mathrm{t} \mathrm{ha}^{-1}$ and $9.18 \mathrm{t} \mathrm{ha}^{-1}$. Significantly lower values were recorded with fallowchickpea treatment.

Application of crop residues for two consecutive years improved the soil carbon content and showed positive response on chickpea crop growth and yield. This shows that crop residue incorporation technique is an important synergistic cultural practice to promote the way to mitigate the increased carbon content of the environment. Varalakshmi et al. (2005) also reported higher organic carbon content in groundnut- wheat cropping system.

\section{CONCLUSION}

In a nutshell, by the end of the experiment, greengram chickpea cropping system had greater SYI values than foxtail millet-chickpea cropping system, owing to higher organic carbon and added biological nitrogen. Due to single-season yields, the fallow - chickpea cropping system had lower SYI values. Gross and net returns, as well as the $\mathrm{B}: \mathrm{C}$ ratio, were higher with the foxtail millet-chickpea cropping system than with the greengram-chickpea cropping system on an equivalent yield basis. When using a fallow-chickpea system, the lowest returns were obtained. In the rainfed vertisols of Andhra Pradesh, double cropping systems combined with crop residue incorporation techniques have proven to be a crucial synergistic cultural practice and ideal productive cropping systems in light of changing climate.

Conflict of interest: None.

\section{REFERENCES}

Amgain, L.P., Shrma, A.R., Das, T.K and Behera, U.K. (2013). Effect of residue management on productivity and economics of pearlmillet based cropping system under zero till condition. Indian Journal of Agronomy. 58(3): 298-302.

Dudhatra, M.G., Vaghani, M.N., Kachot, N.A. and Asodesia, K.B. (2002). Integrated input management in groundnut (Arachis hypogaea L.)- wheat (Triticum aestivium L) cropping system. Journal of Agronomy. 47(4): 482-486.

Hashim, M, Dhar, S., Vyas, A.K., Ramesh, V. and Kumar, B. (2015). Integrated nutrient management in maize (Zea mays L)wheat (Triticum aestivum L.) cropping system. Indian Journal of Agronomy. 60(3): 352-359.

Jain, N.K., Singh, H. Dashara, L.N. and Mundar, S.L. (2015). Maize (Zea mays L.)- wheat (Triticum aestivum L.) cropping system: Intensification through introduction of pulses. Indian Journal of Agronomy. 60(3): 347-351.

Pacharne, D.P., Kathepuri, J.V. and Gawade, M.H. (2018) Studies on groundnut based diversified cropping system including onion (Allium cepa L.) Journal of Allinum Research. 1(1): 81-88.

Tomar, S.S. and Tiwari, A.S. (1990). Production, potential and economics of different cropping sequences. Indian Journal of Agronomy. 35(1-2): 30-35.

Vrakashmi, L.R., Srinivasamurthy, C.A. and Bhaskar, S. (2005). Effect of integrated use of organic manures and inorganic fertilizers on organic corbon available $\mathrm{N}, \mathrm{P}$ and $\mathrm{K}$ in sustaining productivity of groundnut (Arachs hypogaea L.) cropping system. Journal of the Indian Society of Soil Science. 53(3): 315-318. 